\section{RIMCIS \\ Social Sciences}

\section{Hipatia Press}

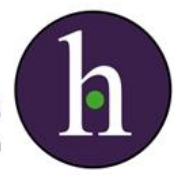

Instructions for authors, subscriptions and further details:

http://rimcis.hipatiapress.com

\title{
Sociological Theory from Dialogic Democracy
}

Elisabeth Torras-Gómez ${ }^{1}$, Mengna Guo ${ }^{1}$, Mimar Ramis ${ }^{1}$

1) University of Barcelona, Spain

Date of publication: November $30^{\text {th }}, 2019$

Edition period: November 2019 - February 2020

To cite this article: Torras-Gómez, E., Guo, M., \& Ramis, M.M. (2019).

Sociological Theory from Dialogical Democracy. International and

Multidisciplinary Journal of Social Sciences, 8(3), 216-234. doi:

10.17583/rimcis.2019.4919

To link this article: http://doi.org/10.17583/rimcis.2019.4919

\section{PLEASE SCROLL DOWN FOR ARTICLE}

The terms and conditions of use are related to the Open Journal System and to Creative Commons Attribution License (CC-BY). 


\section{Sociological Theory from Dialogical Democracy}

Elisabeth Torras-Gómez

University of Barcelona

Mengna Guo

University of Barcelona
Mimar Ramis

University of Barcelona

\section{Abstract}

Despite the long dialogical tradition both in Eastern and Western societies, in recent years the social dialogical turn is more and more evident in many domains of life. Citizens increasingly demand to have a saying in the seeking of solutions for their problematics, and advocate for a more democratic approach to science that fosters the inclusion of all voices and enhances the agency of citizens in social transformation. Therefore, global scientific research is progressively more oriented towards co-creation as a means to ensure social impact. In this context, social theory can provide the theoretical foundations to better address the societal challenges of concern, as well as the mechanisms to properly design research oriented to produce social impact, such as communicative methodology, and to monitor and evaluate such impact. Social theory would then serve its ultimate goal: to contribute to the improvement of societies. Sociology was born as part of the democracies to provide citizens with elements of analysis that would make it possible for them to make their decisions with the prior evidence of the consequences of each option. After a process of democratization, we return to the original sense, but now in a more democratic situation.

Keywords: dialogic democracy, communicative methodology, social impact, cocreation, citizenship 


\section{Teoría Sociológica desde la Democracia Dialógica}

Elisabeth Torras-Gómez

University of Barcelona

Mengna Guo

University of Barcelona
Mimar Ramis

University of Barcelona

\section{Resumen}

A pesar de la larga tradición dialógica tanto en las sociedades orientales como occidentales, en los últimos años el giro social dialógico es cada vez más evidente en más y más ámbitos de la vida. Los ciudadanos demandan que su voz sea tenida en cuenta en la búsqueda de soluciones para sus problemáticas, y abogan por un enfoque más democrático de la ciencia que fomente la inclusión de todas las voces y mejore la agencia de los ciudadanos en la transformación social. Por lo tanto, la investigación científica global está progresivamente más orientada hacia la cocreación como un medio para garantizar el impacto social. En este contexto, la teoría sociológica puede proporcionar los fundamentos teóricos para abordar mejor los desafíos sociales de interés, así como los mecanismos para diseñar adecuadamente la investigación orientada a producir impacto social, como la metodología comunicativa, y para monitorear y evaluar dicho impacto. Desde este enfoque, la teoría sociológica servirá entonces a su objetivo final: contribuir a la mejora de las sociedades. La sociología nació como parte de las democracias para proporcionar a los ciudadanos elementos de análisis que les permitieran tomar sus decisiones con la evidencia previa de las consecuencias de cada opción. Después de un proceso de democratización, volvemos al sentido original, pero ahora en un contexto más democrático.

Pallabras clave: democracia dialógica, metodología comunicativa, impacto social, co-creación, ciudadanía 
W hen Michael Burawoy visited the community of researchers CREA he said, 'I speak of public sociology, but you do not only describe it, you also do public sociology'. The communicative methodology developed by this research community contributes to a dialogic construction of knowledge that not only eliminates the relevant methodological gap between the researcher and the researched subject, as Habermas had proposed, but also achieves the political and social impact that citizenship in democratic societies demand today. The European Commission, in its new research framework program Horizon Europe, has already defined the indicators that will assess the political and societal impact. Moving away from the often wield criticism that such evaluation only favors applied research - anchored in dichotomies already overcome today, the framework of dialogic democracies demands a sociological theory that is able to support the social creations that make these impacts possible and, in short, that contributes to the improvement of society.

It has almost been forty years since Habermas (1987) raised the issue of the disappearance of the qualitatively relevant gap between the researcher and the person under research. Hence, the hierarchical relationship that placed social theorists as the ones who could see beyond the common sense of researched people disappeared. The social movements of recent years have challenged these hierarchical relationships with slogans such as 'they do not represent us' or "not in my name". Earlier, as well, in the big demonstrations, the representatives of big organizations, who were also speaking at the final conferences, were in the front row. That is also changing. There are cultural groups, such as the Roma people, who are pronouncing themselves in an increasingly majority way against investigations that are not carried out with communicative methodology; they do not accept others to talk about them without their voices being equally considered. All these changes are part of the progress of dialogic democracy in more and more countries and areas, thus recovering the original sense of democracies as Elster rigorously analyzed. And it is, in fact, in democratic societies and in the demands towards more dialogic democracies, that science becomes in turn more democratic and dialogic following those same movements and processes. 
A part of sociological theories is oriented more or less intensely to direct collaboration in this dialogic democracy. The goal of those who are dedicated to it is not to make many conferences, publish many books, some of which, as Giddens said in his last years, were to be sold in airport bookstores. On the contrary, the objective is to make theoretical contributions together which citizenry in order to foster democratic transformations. That objective is what Burawoy (2014) described as organic public sociology, referring to the Gramscian concept of organic intellectuals who make contributions, in this case from sociological theory and research, to foster social transformation. In this line, we define with the concept of social creations (Aiello \& Joanpere, 2014; Soler-Gallart, 2017) all those contributions from the social sciences that manage to transform realities, such as creating jobs where there is unemployment, as improving educational results where there is failure, or as generating social cohesion where there was violence. Just as in the medical sciences, where a discovery that enables a new vaccine or a new treatment is made, and thus, creates something new that improves people's lives; in the social sciences there are sociologists who contribute social creations that also contribute to the improvement of the life of all citizens.

Indeed, the emergence of social sciences is linked to that of democracies. Citizens demanded evidence with which they could effectively exert their newly gained freedom. This required science-based knowledge that allowed to understand the consequences of each possible option prior to making a choice. Thus, this dialogic turn reconnects sociological theories with their original aim, by providing new solutions that now incorporate a type of knowledge - the experience of lay people - that has often been disregarded and disdained from science.

However, the dialogic approach does not only exist in Western countries, but also in Eastern countries, even with roots in their ancient cultures, as is the case of the Indian tradition, The Nobel Economy Prize laureate Amartya Sen, in his book The argumentative Indian (Sen, 2005), explains that already in the ancient epics of the Ramayana and the Mahabharata, the two major epic poems of the Indian culture full of arguments and counter-arguments supporting the continuous debates, contrary antagonistic moral positions and viewpoints were often confronted through dialogue. An example of this are 
the doubts and arguments of Arjuna and Krishna, two characters in the Mahabharata. Their discussions are still very relevant in the contemporary world: one must commit to his/her personal duty; but must he/she do so at any cost? This idea can be linked to Weber's contribution moving from ethics of intention to ethics of responsibility where, beyond our intentions, the consequences of our acts need to be taken into consideration as well. In the same nature, and delving into the study of dialogue and argumentation, Arjuna and Krishna's debates -and the ways these dialogues led to- can also be linked to Habermas' elaboration of the above-mentioned Webberian concept, making the original contribution more dialogic.

At a political level, the plurality of options and the respect towards all of them also follows a long tradition in the Indian society. This can be seen in the early Indian Buddhists, who highly vindicated dialogue as a means for social progress, as well as on the ruler Ashoka, who in the third century BC formulated one of the earliest rules for public discussion. In a similar vein, Emperor Akbar strongly supported open dialogue based on reasoning as the tool to address disagreements between those with different faiths. Thus, the preservation of democracy or the defense of secularism in India find its roots in the heterodoxy of thoughts and beliefs and the public debate around them that has traditionally been guaranteed (Sen, 2005). In this vein, the dialogic approach and the argumentative nature of the Indian tradition are key elements that allow to explain the seeking of social justice and the overcoming of social inequalities. Indeed, far from being something exclusive of the elites, language and dialogue offer all individuals, even the most excluded ones, the opportunity to have a saying in any matter of concern. In this line, dialogue, when set on an egalitarian basis, puts all participants, no matter their origin, status or studies, at the same level, since the strength of claims is based on the validity of the arguments that support them rather than on rethorics or power relations.

Moreover, dialogism has also roots in the Chinese tradition. The Analects, one of Confucius (2019) classic works, gathers that one should never 'feel embarrassed to ask and learn from lesser people (5.15)' (in Chinese: Bu Chi Xia Wen) or, in a similar vein, that 'When three people walk together, there must be one person who is a teacher (7.22)' (in Chinese: San Ren Xing, Bi You Wo Shi Yan). These ancient teachings highlight how all 
individuals are capable of making sense about the world around them and transmit that knowledge to others. Because of life experiences, each individual's ways and methods of learning and understanding are different. This implies that taking as many different perspectives into account as possible contributes to unveiling new insights of the issue under study. Similarly, the "Book of Documents" (Chinese: Shu Jing/ Shang Shu) (Anonymous, 2009), which is the earliest compilation of historical documents in China (Shen \& Qian, 2019), highlights that 'someone who likes to ask, will have ample knowledge, but if someone only relies on himself instead of communicating with others, his knowledge will be shallow' (Chinese: Hao Wen Ze Yu, Zi Yong Ze Xiao). Thus, the idea of the intersubjective construction of knowledge was already present in ancient China, were intellectuals following the Confucian teachings understood how a deeper understanding of the world can only be reached in interaction with others.

In line with the dialogic turn of societies (Giddens, Beck \& Lash, 1994; Habermas, 1987), this tradition shifts the focus from positions of power those from lesser positions ought to learn from those in higher stands- to the acknowledgement that everyone has something to contribute and everyone can become a teacher as every person has cultural intelligence (Flecha, 2000). In this context, dialogue becomes the tool to build collective meanings that go beyond the addition of individual understandings. Indeed, communicative interactions allow for intersubjective constructions of knowledge in which the contributions of the participants are collectively shared, contrasted and reformulated into new knowledge that could not have been reached outside of the debate (Flecha, 2000). Han Yu, an important Confucian intellectual who influenced later generations of Confucian thinkers and Confucian philosophy (Shen \& Shun, 2008), listed the positive and negative examples in his argumentative writing "Shi shuo". He emphasized that having a dialogue with the teacher was necessary to achieve the purpose of learning and he highlighted that regardless of the status, the age or the location the truth exists where teaching exists, thus acknowledging the potential of any individual to be both teacher and student in communicative interactions. 
In the history of China, one of the most flourishing period of schools and thoughts was during the Spring and Autumn period (770 BC - $476 \mathrm{BC}$ ) and the Warring States period (475 BC - 221 BC) of ancient China (Tan, 2012). This time is known as the period of "Hundred Schools of Thought". In its context, the place that promoted the prosperity of different ideas and provided an equal and free dialogue environment was the Academy of the Gate of Chi (Chinese: Jixia Xue Gong) which almost simultaneously emerged with the Plato Academy in Greece (Needham \& Ling, 1956). The Academy of the Gate of Chi gathered several philosophical schools such as Confucianism, Taoism, Mohist, Legalist, Logicians, all of which have been active in promoting the principles of free debate, mutual absorption, integration and development (Zhang, 2009; Zhao \& Chen, 2019). In short, the dialogic approach present in ancient Chinese culture and school reached its peak in that period and it still has a wide impact in China today.

\section{Communicative Methodology and Dialogic Construction of Knowledge}

Now, recent changes in all sciences create possibilities for contributing from research to the development of more dialogic societies. Among these, one can find the communicative methodology, its relationship with the concept of co-creation - or dialogic creation of knowledge - and how that process contributes to the advancement of dialogic democracies. As well, the orientation towards social impact and its evaluation in scientific research programs are also discussed as a step forward in this democratic advance of society.

Communicative methodology of research involves in every step of research the people or the communities which are the focus of the study. Following this approach, both researchers and research subjects are invited to participate in an egalitarian dialogue; the former provide the expert knowledge and science-based evidence, will the latter provide their experience and their understanding of the context under study. Thus, communicative methodology seeks and promotes an active participation of citizens in science, including that of those vulnerable groups and minorities which are often excluded from scientific research. This approach has a twofold benefit: on the one hand, it provides tailored evidence-based 
solutions that scientists on their own would not have been able to find. On the other hand, it actively engages citizens in the improvement and transformation of their social realities (Gómez, Padrós, Ríos, Mara \& Pukepuke, 2019).

Almost two decades after it was first applied, Communicative Methodology has allowed to unveil evidence of transformative and exclusionary practices and elements for the contexts under research, allowing to foster the former and to overcome the latter; informing, in turn, citizens, scientists and policies that then incorporate the generated knowledge to improve people's lives (Valls \& Padrós, 2011).

Indeed the fundamental postulates of Communicative Methodology include: language and action as inherent and universal attributes of all human beings; all individuals' capacity of agency and social transformation; the use of language based on communicative rationality to reach understanding, the consideration of lay people's common sense as valid knowledge, the abolition of the interpretative hierarchy based on power relations in favor of egalitarian interpretations, the creation of spaces that guarantee the equal epistemological level of all participants and the understanding of the dialogic nature of knowledge, as a result of intersubjective interactions.

Thus, unlike in ethnographies, participant research or action research (to name a few), the main objective of communicative methodology of research is the dialogue set between the accumulated knowledge in the scientific community and the experience lived from everyday life. Therefore, communicative methodology does not intend to collect the voices of the people being researched, but to dialogue with them in an egalitarian basis. Following this idea, the researcher does not participate in the researched context as if he were an equal, but, being aware of his position of power, he or she establishes the basis for an egalitarian dialogue (in the sense of Habermas, 1987).

The analysis of the communicative acts in the research process shows us how there are power interactions, from the fieldwork to the creation of advisory bodies with representatives of the citizens that are the target of that investigation. Only through the acknowledgement of their existence, these power relationships can be overcome, while, at the same time, the dialogic 
communicative acts between researchers and researched subjects can be achieved (Sordé \& Ojala, 2010).

\section{Co-creation, Impact and Dialogic Democracy}

Encouraging people to engage and participate in science is a practice that falls far in time. Before the emergence in the 19th century of science as a discipline there are some accounts of amateur scientists engaging nonexperts in the collection of data around natural history observations (MillerRushing, Primack \& Bonney, 2012). This type of participation allowed for the building of key collections of animals, plants and minerals, among others, and highly contributed to the advancement of the scientific fields that promoted these practices (Miller-Rushing et al., 2012). In fact, this kind of contributions not only continued with the professionalization of science but also got progressively perfected, providing researchers with extensive amounts of datasets that would otherwise have been impossible to gather through with only the involvement of scientists. Moreover, technological advancements and the development of the Internet and connected devices deeply boosted this collaboration, both in terms of citizens involved and data collected (Bonney, Phillips, Ballard \& Enck, 2016). For instance, in medicine (Chrisinger \& King, 2018), citizens can now participate in science through monitoring their well-being through the use of modern apps or through the promotion of healthier habits (Chrisinger et al., 2018). However, these kinds of collaborations follow the same style as in the 1900s, where citizens carried out fieldwork, merely observing, taking pictures and counting.

Thus, citizen participation in science needed to be reviewed in order to ensure that the voices of research subjects were included and taken into account in every step of research. This meant actively engaging citizens in finding solutions to their own problems and ensuring to a larger extent the social impact of the outcomes of scientific research. In this context, the concept of co-creation re-emerged with the aim to give citizens the spot they deserve in scientific research, not as passive providers of data, but as active agents in the creation of scientific knowledge. 
However, and once again, this idea is not exclusively a Western development. In ancient China, the participation of different schools of thought in the period of "Hundred Schools of Thought" had and effect not only at the time where the knowledge developments were taking place, but also in contemporary China. The impact is not only at an intellectual level, but also at a social one. Gu Yanwu (2017), who follows the ideology of Confucianism emphasizes the responsibility of all citizens to construct a better society. The author states the difference between "Desperate country" (Wang Guo) and "Desperate society" (Wang Tian Xia) and he also emphasizes the consistency of the individual and society, understanding society as the enlargement of the family. In Ri Zhi Lu, he suggests the idea that the 'rise and fall of a society rests with every one of its citizens' (Chinese: Tian Xia Xing Wang, Pi Fu You Ze). Therefore, any citizen has the inherent capacity to contribute to the improvement of the society in which he or she lives. These ideas are linked to the concept of co-creation.

Co-creation refers to the participation of citizens in the creation of scientific knowledge together with those who work professionally in this task. The first example of scientific research with social impact based on cocreation principles within the European Framework of research is that of WORKALÓ (WORKALO Consortium, 2001-2004). WORKALO was an FP5 research project, coordinated by CREA, which incorporated in all phases of research the participation of subjects traditionally excluded from the scientific community and debates, as the Roma community. In one of the training seminars organized within its framework, Professor Michele Wieviorka was presenting his concept of mixed identities. He explained how people whose families shared different origins experienced different identity fractions. According to the professor, someone who had different or shared different origins from the country in which he or she lived could feel, for instance 50\% Algerian and 50\% French. In that same seminar, attended by citizens of different cultural groups, a young Roma woman raise her hand to intervene in a forum with scholars and other stakeholders and told him 'I do not agree with your statement because I am Roma and French and I do not feel 50\% Roma and 50\% French, but 100\% Roma and also 100\% French'. To this intervention, the sociologist replied, 'I will have to check my concept'. When research and the subsequent process of knowledge 
production follow these dialogic processes, sociological theory contributes to social improvements that impact citizens and the societies involved. Thanks to this process, non-academic Roma people made key contributions to the WORKALO research project, the results of which were approved by the European Parliament in 2005 and by other parliaments of member states that have made possible concrete policies and programs that have led to direct improvements in the life of Roma people.

Co-creation became already a keyword in Horizon 2020 and it is now at the very core of the Horizon Europe framework programme, informed on social theory. Indeed, in Horizon Europe, one further step is taken, since citizen participation is considered an essential part of social impact. Hence, this participation becomes evaluable and decisive for the approval of projects ex-ante, as well as in-itinere and ex-post. In fact, placing social impact at the core of research puts us on the path to a transformative relationship between science and society based on the improvement of society through the results and findings of research projects. This brings up a new scenario in which sociology and especially social theory, become particularly relevant and necessary. However, there is a part of sociological theory that does not agree with that process and will continue to make contributions to the social sciences and society from other perspectives. But there is also another part of sociological theories that not only addresses that challenge but is already co-directing the current transformations of all sciences and their consequences for the transformations of society.

The European Commission has decided to guide its new research framework program, Horizon Europe, following the document "Monitoring the impact of EU Framework Programs" (van den Besselaar, Flecha, \& Radauer, 2018) in which the foundations on how to collect scientific, economic, political and societal impacts in science are laid. The pathway impact indicators highlight the path to the UN sustainable development goals - global goals for all citizens - and the path for citizens to be able to benefit from the knowledge created and research results. This social impact is achieved in the short, medium and long term. The short-term refers to the process of co-creation of knowledge with citizens; the medium-term to the use that citizens make of that knowledge beyond the research project, and the long-term, to the appropriation of knowledge and social improvements 
experienced by the citizens themselves. The sociological theory that is linked to this dialogic co-production of knowledge based on a communicative approach is already in line with what is now a priority in Europe, as well as in advanced sciences in general.

The orientation of research towards social impact is part of the transformation of science within the framework of societies that want to be increasingly more democratic. Indeed, a new wave is now democratizing the scientific system with the concepts of "open access" and "open science" including FAIR principles (findable, accessible, interoperable and reusable) that alludes with a pun to what is 'just' for science and humanity. There are top-level scientific journals such as PLoS that in two weeks can make a scientific discovery available not only to colleagues in their discipline, but to all citizens. Movements such as scientific literacy (which are not new, but now recovered) or the "march for science", are realities that indicate that citizens want to know and want to participate when they see that science improves their lives.

However, these advancements rely in many cases on ancient practices and classic social theory contributions. For instance, Sen (2005) explains that in the introduction of the first ever printed book with a date, an 868 Chinese translation of a Sanskrit text (Dimond Sutra, 402 CE), it could already be read that the book could be freely distributed. Also, as mentioned above, one of the essences of the Confucian learning methods is communicative interaction. In this vein, learning and the development of knowledge and though highly depend on dialogue with intellectuals as well as with lay people.

More recently, in the nineteenth century Weber stated that social theory is necessary to orient social research. Weber's (2004) Ethics of Responsibility is a highly relevant concept when considering social impact. This concept gives us a key to orient our work since it reminds us that is not the means we use in our research what matters most but is the results it produces. As well, the science system that Merton (1968) studied, with its functions and dysfunctions, has undoubtedly been an advance at the service of humanity, surpassing what was once sacred, opaque or incomprehensible to the majority and in the service of a few. Moreover, Merton's (1968) Ethos of science is behind current scientific advancements such as the open access 
movement or the emergence of repositories such as the Social Impact Open Repository - SIOR, the first scientific repository in which research projects with social impact are indexed. Merton's contributions also remind us that even if technocrats want to narrow the approach to social impact to rankings and indicators, what it is truly necessary is to return to theoretical contributions and build from those, on the shoulders of giants.

Nevertheless, the contributions of social research to social impact have not only been top-down, from theory to practice, but also bottom-up. An example of this is that of Real Utopias, conceptualized by Erik Olin Wright (2011). Following this idea, social theory can provide the keys to understand the conditions under which these realities emerge, so they can be replicated and transferred to other contexts. An example of how this emancipatory social sciences approach can be applied to research is that of the research project SOLIDUS (Solidus Consortium, 2015-2018). In this case, theory and a rigorous methodological design allowed for the identification of the indicators of transformative solidarity actions through the case study of solidarity actions in Europe.

Another case of bottom-up contribution to social impact from social theory is Burawoy's public sociology, aforementioned. This sociological approach, directed at providing answers for social needs, has succeeded at making sociologist aware of the need to consider societal concerns and provide an explanation from research. This contributes to the creation of new knowledge around SSH that emerges directly from societal problematics as an answer to those problematics. An example of these are all the research within the field of sociology that are being produced in order to give an explanation to the social determinants around cases of gender based violence, for instance, or the focus on the UN's SDG.

\section{Collective Contributions to Theory and Democracy}

Today the creation of knowledge, in all disciplines, is not understood without collaborative teamwork, without collaboration with the other colleagues who are on those same issues around the world based on open knowledge. But moreover, nowadays the demand is focused on the collaborative work of social theorists and scientists in dialogue with citizens, 
establishing co-creation processes that have the potential to transform social realities or which are already doing it.

Creating knowledge nowadays in any scientific discipline is more than ever the result of interaction, of different scientists from also different disciplines, providing their knowledge, but also creating new one, through their cooperation. Knowledge has become more open and free and anyone can add onto others' developments through different means for the sake of scientific progress. There are many initiatives based on an open dialogue meant to improve science and also our lives such as the Wikipedia dynamic process of knowledge creation and improvement, or the European Union's public consultations on a wide array of topics. All these initiatives aim at responding to citizen's expressed needs (Consultations, 2019).

Interaction and cooperation have always improved knowledge, although the current moment is the best one in history in terms of increased contexts of interaction that facilitate this progress. What is now facilitated through online open dialogue and collective creation of knowledge, was once extraordinary. In a seminar with Ulrich Beck, a bachelor student alerted him that he was saying just the opposite of what his own book said. When he replied inquiring about the reasons why she said that, she indicated the specific page where he had written it. Instead of getting angry, he exclaimed: 'Where is the miracle?'. The student had read all of his books and was also part of a Seminar With the Book in Hand where researchers from different disciplines, academic categories and professions, read the main works of social sciences and other sciences (eg Weber's Economy and Society, Adam Smith's Wealth of Nations, Sen's Idea of Justice, Kandel's Principles of Neuroscience, Einstein's Evolution of Physics, etc.) debating from specific paragraphs.

Habermas has made great contributions to sociological theory that have been key pieces and especially in the face of the postmodern and neoliberal offensive of the eighties of the twentieth century, have been key pieces. But working individually has increasing limits in current societies. In this seminar, reading and debating the Theory of Communicative Action and the Speech Acts of Searle, we discovered that Habermas had not understood the Searle's contributions to the theory of speech acts and only partially understood the contributions of the creation of this theory, Austin. Later, we 
had the opportunity to have long and profound talks with Searle. He criticized Habermas for writing a lot about his theory and the theory of his professor and friend Austin without understanding both and making simple mistakes. The same happens, among others, with the theory of Parsons. One member of CREA had the opportunity to talk with Merton about the mistaken analysis. Habermas knows very well several books of Parsons but not at all the last ones, the ones in with develop his idea of societal community. This lack made Habermas to get angry with Parsons theory, abandon his contribution of societal community and replace it by one of the worst concepts elaborated by Habermas: the patriotism of constitution.

If even the best present sociological theorist has this kind of errors, which ones could make the others if we insist on working individually? The future of sociological theory and its contribution to society is promising because an increasing number of young theorists are already working collectively. We are aware that one of us cannot read seriously and profoundly all the books and papers that need to be taken into account in order to elaborate a real social theory. Besides, we are working closer to researchers from other sciences where is very common the collective work; papers from some sciences are signed by many authors, while in social sciences still most of them are signed individually.

The Seminar With the Book in Hand has been one of the main sources of theoretical and social creation of the research community mentioned in this paper. It involves both professors and undergraduate students as well as people outside the university. The only requirement is that to speak you have to reference the page which your idea comes from. This principle of equality, which is in the line of open science and the democratization of science, has made the contributions to the debate much richer. As mentioned before, great intellectuals, like Habermas, however much he has read, cannot cover everything. However, a working team, with people from very different disciplines, occupations, experiences, cultural backgrounds, religions, political options, sexualities, interests, working in a dialogical way can create much more. 


\section{Conclusions}

In this paper we have argued that the dialogic approach has long been present in both Eastern and Western societies. Intellectuals from both traditions have widely pointed at the capacity of humans to learn from one another, beyond status, educational level or age, and to collectively build their understanding of the world. More recently, modern societies have started to experience a dialogic turn that incorporates these traditional ideas in an attempt to further improve democratic societies. In this context, more and more citizens, including those belonging to vulnerable groups, are demanding the inclusion of their voices in different fields, so their experience and viewpoints are also taken into account in the seeking of solutions to overcome the social challenges of our era. This turn is visible in scientific research, where scientists are more and more demanded to plan for the social impact of their research and to gather evidence of the extent to which that impact was achieved. In this scenario, methodologies such as the communicative methodology of research, become increasingly relevant, since they promote the inclusion of all voices and the co-creation of scientific knowledge which citizens as a means to improve both science and society. Drawing on this methodological approach, citizens not only contribute their knowledge at every step of the research but become agents of social transformation. Social sciences were born with democracies, so that citizens would have the necessary knowledge to rule over themselves. Through the principle of co-creation and with scientific impact at the very core of its design, scientific research is serving citizens more than ever, with social sciences leading the shift.

\section{References}

Aiello, E., \& Joanpere, M. (2014). Social Creation. A New Concept for Social Sciences and Humanities. International and Multidisciplinary Journal of Social Sciences, 3(3), 297-313. doi: 
Anonymous (2009). Shang Shu - Book of Documents (L. Shengli, ed.; M. Ping, trans.). Beijing: Zhonghua Book Company.

Bonney, R., Phillips, T. B., Ballard, H. L., \& Enck, J. W. (2016). Can citizen science enhance public understanding of science? Public

Understanding of Science, 25(1), 2-16. doi:

$10.1177 / 0963662515607406$

Burawoy, M. (2014). Precarious Engagements: Combat in the Realm of Public Sociology Guest Editor: Michael Burawoy. Current Sociology.

La Sociologie Contemporaine, 62(2).

Chrisinger, B. W., \& King, A. C. (2018). Stress experiences in neighborhood and social environments (SENSE): a pilot study to integrate the quantified self with citizen science to improve the built environment and health. International Journal of Health Geographics, 17(1), 17. doi: 10.1186/s12942-018-0140-1

Chrisinger, B. W., Ramos, A., Shaykis, F., Martinez, T., Banchoff, A. W., Winter, S. J., \& King, A. C. (2018). Leveraging Citizen Science for Healthier Food Environments: A Pilot Study to Evaluate Corner Stores in Camden, New Jersey. Frontiers in Public Health, 6, 89. doi: 10.3389/fpubh.2018.00089

Confucius, C. (2019). The Analects of Confucius. Books on Demand. Consultations (2019, November 25). Retrieved November 25, 2019, from European Commission - European Commission website:

https://ec.europa.eu/info/consultations/

Flecha, R. (2000). Sharing Words: Theory and Practice of Dialogic Learning. New York: Rowman \& Littlefield Publishers.

Giddens, A., Beck, U., \& Lash, S. (1994). Reflexive modernization: Politics, tradition and aesthetics in the modern social order. Stanford University Press.

Gómez, A., Padrós, M., Ríos, O., Mara, L.-C., \& Pukepuke, T. (2019).

Reaching Social Impact Through Communicative Methodology.

Researching With Rather Than on Vulnerable Populations: The Roma

Case. Frontiers in Education, 4, 9. doi: 10.3389/feduc.2019.00009

Gu, Y. (2017). Ri Zhi Lu (R. Zheng, Ed.). Retrieved from 古诗文网

(Ancient Poetry Network) website https://so.gushiwen.org/ 
Habermas, J. (1987). Teoría de la acción comunicativa. Vol. I-II. Madrid: Taurus.

Merton, R.K. (1968). Social Theory and Social Structure. Free Press.

Miller-Rushing, A., Primack, R., \& Bonney, R. (2012). The history of public participation in ecological research. Frontiers in Ecology and the Environment, 10(6), 285-290. doi: 10.1890/110278

Needham, J., \& Ling, W. (1956). Science and Civilisation in China, vol. 1: Introductory Orientations (Vol. 1). Cambridge: Cambridge University Press.

Sen, A. (2005). The Argumentative Indian: Writings on Indian Culture, History and Identity. London, Penguin Books.

Shen, Q., \& Shun, K. L. (2008). Confucian Ethics in Retrospect and Prospect. Council for Research in Values \& Philosophy

Shen, S., \& Qian, Z. (2019). 本体诠释学视角下的西方《尚书》英译研究. 湖南师范大学教育科学学报 (A Study of English Translations of Shang Shu in the West from the Perspective of Ontological Hermeneutics. Journal of Social Science of Hunan Normal University), 97-107. doi: 10.19503/j.cnki.1000-2529.2019.05.012 Soler-Gallart, M. (2017). Achieving Social Impact: Sociology in the Public Sphere. Springer.

Solidus Consortium. (2015-2018). SOLIDUS: Solidarity in European societies: empowerment, social justice and citizenship. Horizon 2020. Horizon 2020. European Commission.

Sordé, T., \& Ojala, M. (2010). Actos comunicativos dialógicos y actos comunicativos de poder en la investigación. Revista Signos, 4(2), 377391. doi: 10.4067/S0718-09342010000400008

Tan, S. (2012). 论春秋战国时期的百家争鸣. 兰台世界. (Hundred Schools of Thought in the Spring and Autumn Period and Warring States Period. Lantai World), 30, 67-68. doi: 10.16565/j.cnki.10067744.2012.30.031

Valls, R., \& Padrós, M. (2011). Using Dialogic Research to Overcome Poverty: From principles to action. European Journal of Education. doi: 10.1111/j.1465-3435.2011.01473.x

van den Besselaar, P., Flecha, R., \& Radauer, A. (2018). Monitoring the Impact of EU Framework Programmes. doi: 10.2777/518781 
Weber, M. (2004). The Vocation Lectures. Hackett Publishing.

WORKALO Consortium. (2001-2004). WORKALO. The creation of New occupational patterns for cultural minorities. The Gypsy case.

European Commission FP5.

Wright, E. O. (2011). Real Utopias. Contexts, 10(2), 36-42. doi:

$10.1177 / 1536504211408884$

Zhang, S. (2009). 稷下学宫的办学理念及其当代意义.

湖南师范大学教育科学学报 (Idea of Ji Xia Xue Gong and Its Contemporary Significance. Journal of Educational Science of Hunan Normal University), 8(5).

Zhao, Z., \& Chen, X. (2019). 试探稷下学宫的特点和性质. 文史杂志 $(\mathrm{On}$ the Characteristics and Nature of the Palace of Study. Journal of Literature and History), 6.

Elisabeth Torras-Gómez is a predoctoral researcher at the University of Barcelona.

Mengna Guo is a Ph.D. Candidate at the University of Barcelona.

Mimar Ramis is Assistant Professor at the University of Barcelona.

Email: etorras@ub.edu 